\title{
ANALISIS PENERAPAN MEDIA BERBASIS KOMPUTER PADA PEMBELAJARAN TEMATIK TERPADU DI SEKOLAH DASAR
}

\author{
Kuncahyono \\ Pendidikan Guru Sekolah Dasar, Universitas Muhammadiyah Malang \\ E-mail: kuncahyono@umm.ac.id
}

\begin{abstract}
Teachers in delivering materials need intermediate tools to make the delivery of material easier and more targeted. The way is by using the learning media. One of the learning media that can be used by teachers in learning is computer-based media. The purpose of this study is to determine the ability and knowledge of teachers in applying computer-based learning media, constraints and efforts undertaken by teachers in applying the media. The type of this research is descriptive research with qualitative approach. This research was conducted in SD Muhammadiyah 9 Malang with the subject of research class III to class V which amounted to 3 people. Then the technique of data collection using observation, interview, documentation, and questionnaire. The results of this study describes teachers have been able to apply computer-based media. Teachers are skilled in utilizing technological means and developing material into an interesting computer-based media product, and easy to apply in learning. There is no significant obstacle for teachers in implementing computer-based learning. Efforts by teachers that is by self-development through training and utilization of facilities and infrastructure already provided by the school intelligently.
\end{abstract}

\section{Keywords: Computer Based Media, Learning, Integrated Thematic}

\begin{abstract}
ABSTRAK: Guru dalam menyampaikan materi memerlukan alat bantu perantara agar proses penyampaian materi lebih mudah dan tepat sasaran. Adapun cara tersebut yaitu dengan menggunakan media pembelajaran. Salah satu media pembelajaran yang dapat digunakan guru dalam pembelajaran yaitu media berbasis komputer. Tujuan dari penelitian ini adalah mengetahui kemampuan dan pengetahuan guru dalam menerapkan media pembelajaran berbasis komputer, kendala dan upaya yang dilakukan guru dalam menerapkan media tersebut. Jenis penelitian ini adalah penelitian deskriptif dengan pendekatan kualitatif. Penelitian ini dilaksanakan di SD Muhammadiyah 9 Malang dengan subjek penelitian guru kelas III sampai dengan kelas V yang berjumlah 3 orang. Kemudian teknik pengumpulan datanya dengan menggunakan observasi, wawancara, dokumentasi, dan kuesioner. Hasil penelitian ini menggambarkan guru-guru sudah mampu menerapkan media berbasis komputer. Guru sudah terampil dalam memanfaatkan sarana teknologi dan mengembangkan materi menjadi produk media berbasis komputer yang menarik, dan mudah diaplikasikan dalam pembelajaran. Tidak ada hambatan yang berarti bagi guru dalam menerapkan pembelajaran berbasis komputer. Upaya yang dilakukan guru yaitu dengan pengembangan diri melalui pelatihan dan pemanfaatan sarana dan prasarana teknogi yang sudah disediakan oleh sekolah secara cerdas.
\end{abstract}

Kata kunci: Media Berbasis Komputer, Pembelajaran, Tematik terpadu

\section{PENDAHULUAN}

Fakta di lapangan $\begin{array}{r}\text { terkait } \\ \text { perkembangan } \\ \text { teknologi }\end{array}$ dapat
meningkatkan kualitas sumber daya
manusia jika diaplikasikan dengan baik
dan cerdas. Keberadaan teknologi
mengalami kemajuan yang luar biasa
terutama jaringan informasi dan
komunikasidengan ditandai munculnya
beragam pealatan teknologi informasi
seperti handphone smartphone,
komputer, maupun laptop serta
perkembangan jaringan internet global.
Perkembangan teknologi yang
mengalami kemajuan berdampak

terutama dalam kegiatan pembelajaran di kelas. Hal ini dapat dibuktikan banyaknya sekolah yang menerapkan teknologi dalam kegiatan pembelajaran di kelas. Melalui pemanfaatan teknologi di kelas menjadikan pembelajaran berdampak positif dan menarik. Hal ini sesuai dengan hasil penelitian Arkün (2008:16) menghasilkan kesimpulan bahwa produk media berbasis teknologi yang digunakan dalam pembelajaran di kelas IV sekolah dasar berdampak positif bagi prestasi siswa. Penelitian ini menunjukkan bahwa siswa juga merasa tertarik dan senang belajar menggunakan media berbasis teknologi. 
Dewasa ini sebagai bentuk imbas dan respon positif terkait perkembangan teknologi, pemerintah juga menggencarkan Kurikulum 2013 meskipun kurikulum terus mengalami perubahan seiring perkembangan teknologi. Sebagai respon positif itulah pemerintah memberikan fasilitas berupa buku guru maupun buku siswa yang mudah diakses secara online oleh guruguru maupun siswa.

Selain kemudahan dalam mengakses bahan ajar, guru-guru juga dituntut untuk lebih inovatif dan kreatif teruatama menyikapi kebijakan dalam menerapkan pembelajaran menggunakan media berbasis komputer yaitu dengan cara guru melek teknologi. Guru harus mampu menerapkan, bahkan mampu mengembangkan inovasi media pembelajaran berbasis komputer.

SD Muhammadiyah 9 Malang merupakan Sekolah dasar yang mengedepankan literasi internet berbasis web. Hadirnya fasilitas internet dapat dimanfaatkan guru selaku pendidik sebagai sarana transfer informasi materi interaktif ke siswa sehingga memudahkan pelaksanaan kegiatan belajar mengajar di kelas. Dapat dikatakan dengan kehadiran berbagai macam alat teknologi tersebut mendorong banyak sekolah ikut terlibat dalam memanfaatkan sarana teknologi dan informasi untuk menunjang pembelajaran.

Berdasarkan hasil observasi lapangan yang dilakukan peneliti di SD Muhammadiyah 9 Malang pada bulan Maret 2017 didapatkan fakta bahwa SD Muhammadiyah 9 Malang sudah menerapkan kurikulum 2013, guru-guru sudah menerapkan pembelajaran tematik terpadu, dan guru-guru juga sudah mencoba mengaplikasikan media dalam kegiatan pembelajaran di kelas. Adapun media yang digunakan juga beragam. Salah satu penerapan media yang dijadikan fokus penelitian adalah penerapan media berbasis komputer.

Berdasarkan pemaparan diatas, maka peneliti tertarik untuk melihat seberapa jauh kompetensi guru dalam menerapkan media berbasis komputer dalam pembelajaran, kendala dalam menggunakan media berbasis komuter, dan upaya yang dilakukan guru dalam mengatasi kendala tersebut. Oleh karena itu, peneliti melakukan penelitian SD Muhammadiyah 9 Malang dengan judul "Analisis Penerapan Media Berbasis Komputer pada Pembelajaran Tematik Terpadu di SD Muhammadiyah 9 Malang"

\section{Hakikat Media Pembelajaran}

Kegiatan pembelajaran tidak hanya merupakan proses interaksi antara guru dan siswa. Salah satu diantaranya yaitu adanya interaksi antara media yang di gunakan guru dengan siswa. Media diartikan sebagai pengantar atau perantara, yaitu sebagai pengantar pesan dari pengirim kepada penerima (Suprihatingrum, 2013:319). Dapat dikatakan bahwa media merupakan alat dan bahan yang berisi informasi atau bahan pelajaran yang bertujuan untuk mempermudah mencapai tujuan pembelajaran.

\section{Klasifikasi Media Pembelajaran}

Berkaitan dengan peran teknologi sebagai media pembelajaran. Klasifikasi media dapat dikelompokkan ke dalam empat kelompok, yaitu; (1) media hasil teknologi cetak, (2) media hasil teknologi audio visual, (3) media hasil teknologi komputer, (4) media hasil gabungan teknologi cetak dan komputer (Arsyad, 2014:31). Teknologi berbasis komputer merupakan cara menghasilkan atau menyampaikan materi dengan menggunakan sumber-sumber yang berbasis mikroprosesor.

\section{Media Pembelajaran Berbasis Komputer}

Komputer merupakan salah satu media pembelajaran yang paling sering digunakan oleh guru saat ini. Hal ini berkaitan dengan tuntutan akan keterampilan menggunakan ICT oleh guru. Oleh karena itu guru selalu update ilmu dan melek teknologi guna menjawab tantangan perkembangan dan kemajuan ICT. Salah satu peran guru dalam meningkatkan keefektifan pembelajaran di kelas yaitu dengan menggunakan media berbasis teknologi. Adapun keungulan media komputer 
dalam pembelajaran yaitu: (Suprihatinngrum, 2013:325)

a. komputer dapat mengajarkan konsep-konsep, aturan, prinsip, langkah-langkah, proses, dan kalkulasi yang kompleks.

b. Komputer berprogram cocok digunakan untuk pembelajaran mandiri

c. Komputer dapat melatih kemampuan motorik siswa jika pembelajaran dikemas dalam bentuk game dan simulasi

d. Komputer juga mampu menyediakan pembelajaran berupa video yang isinya dapat menggugah perasaan dan sikap siswa

Komputer berperan sebagai manajer dalam proses pembelajaran yang dikenal dengan Computer Managed Instruction (CMI). Lebih lanjut peran komputer sebagai pembantu tambahan dalam belajar, pemanfaatannya meliputi penyajian isi informasi materi pelajaran, latihan, atau kedua-keduanya atau disebut juga Computer Assisted Instruction (CAI) (Arsyad, 2014:93).

\section{Pembelajaran Tematik Terpadu}

Pengertian pembelajaran tematik Trianto (2010: 70) adalah pembelajaran terpadu yang menggunakan tema untuk mengaitkan beberapa mata pelajaran sehingga dapat memberikan pengalaman belajar yang bermakna kepada siswa. Sejalan dengan pendapat tersebut, Prastowo (2013:125) menyatakan pembelajaran tematik merupakan proses pembelajaran yang penuh makna dan berwawasan multikurikulum, yaitu pembelajaran yang berwawasan penguasaan dua hal pokok terdiri dari penguasaan bahan (materi) ajar yang lebih bermakna bagi kehidupan siswa serta pengembangan kemampuan berpikir matang dan bersikap dewasa agar dapat mandiri dalam memecahkan masalah kehidupan.

Ditegaskan dalam Permendikbud No 57 tahun 2014 pembelajaran tematik terpadu merupakan pendekatan pembelajaran yang mengintegrasikan berbagai kompetensi dari berbagai mata pelajaran ke dalam berbagai tema. Berdasarkan acuan tersebut dapat dikatakan bahwa pembelajaran tematik adalah pembelajaran menggunakan tema untuk mengaitkan kompetensi dari beberapa mata pelajaran agar siswa mampu mengembangan kemampuan berpikir dan bersikap dewasa agar dapat mandiri dalam memecahkan masalah dalam kehidupan sehari-hari. Tema adalah pokok pikiran atau gagasan pokok yang menjadi pokok pembicaraan. Tujuan dari adanya tema ini bukan hanya untuk menguasai konsep-konsep dalam suatu mata pelajaran, akan tetapi juga keterkaitannya dengan konsep dari mata pelajaran lain.

Lebih lanjut perlu dipahami bahwa pembelajaran tematik merupakan pembelajaran terpadu yang menekankan keterlibatan siswa dalam pembelajaran. Siswa aktif terlibat dalam proses pembelajaran dan pemberdayaan dalam memecahkan masalah, sehingga dapat menumbuhkan kreativitas sesuai dengan potensi dan kecenderungan mereka yang berbeda satu dengan yang lainnya. Sekaligus dengan diterapkannya pembelajaran tematik, siswa dapat belajar dan bermain dengan kreativitas yang tinggi. Hal ini dikarenakan dalam pembelajaran tematik, belajar tidak semata-mata mendorong siswa untuk mengetahui (learning to know), tetapi belajar juga untuk melakukan (learning to do), untuk menjadi (learning to be), dan untuk hidup bersama (learning to live together).

Pembelajaran tematik lebih menekankan pada keterlibatan siswa dalam proses belajar dan mengarahkan siswa secara aktif terlibat dalam proses pembelajaran. Dalam pelaksanaan pembelajaran tematik memiliki beberapa kelebihan dan kekurangan.

Pembelajaran tematik di Sekolah Dasar (SD) memiliki beberapa tahapan yaitu pertama, guru harus mengacu pada tema sebagai pemersatu berbagai mata pelajaran untuk satu tahun. Kedua, guru melakukan analisis standar kompetensi lulusan, kompetensi inti, kompetensi dasar dan membuat indikator dengan tetap memperhatikan muatan materi dari standar isi. Ketiga, membuat hubungan antara kompetensi dasar, indikator dengan tema. Keempat, membuat jaringan KD dan indikator. Kelima, menyusun silabus tematik dan keenam membuat rencana pelaksanaan 
pembelajaran tematik dengan mengkondisikan pembelajaran yang menggunakan pendekatan scientific.

Tema kurikulum 2013 adalah menghasilkan insan Indonesia yang produktif, kreatif, inovatif, afektif melalui penguatan sikap, keterampilan dan pengetahuan yang terintegrasi. Untuk mewujudkan hal tersebut guru di tuntut secara profesional merancang pembelajaran efektif dan bermakna. Pengembangan struktur kurikulum 2013 sedikitnya mencakup tiga langkah kegiatan yaitu mengidentifikasi kompetensi, mengembangkan struktur kurikulum dan mendeskripsikan mata pelajaran. Kegiatan pembelajaran di Sekolah Dasar (SD) dilaksanakan berdasarkan Standar Kompetensi Lulusan (SKL), Kompetensi Inti (KI) dan Kompetensi Dasar (KD).

Dengan demikian, proses pembelajaran harus dilaksanakan dengan dipandu nilai-nilai, prinsip-prinsip atau kriteria ilmiah. Kurikulum 2013 menekankan pada dimensi pedagogik modern dalam pembelajaran, yaitu menggunakan pendekatan ilmiah. Pendekatan ilmiah (scientific approach) dalam pembelajaran sebagaimana dimaksud meliputi mengamati, menanya, mengumpulkan informasi, mengasosiasi dan mengkomunikasikan (Kemendikbud: 2013).

\section{METODE PENELITIAN}

Pada penelitian ini menggunakan penelitian deskriptif, pada penelitian ini yang bermaksud mendeskripsikan terkait situasi-situasi atau kejadian-kejadian sesuai dengan keadaan lapangan.

Rancangan penelitian yang digunakan yaitu deskriptif survei adalah penelitian yang bertujuan mengambarkan suatu fenomena atau melukiskan fakta atau karakteristik populasi tertentu atau bidang tertentu secara sistematis, faktual dan cermat. Desain deskriptif survei tidak digunakan untuk menguji hipotesis dan pengunaan statistik deskriptif (frekuensi, proporsi, mean/rata-rata, median, modus, kuartil, varians, standart deviasi, jumlah, range, nilai maksimun-minimum dsb) untuk mengambarkan apa yang terjadi, lazimnya tidak untuk menerima atau menolak hipotesis.
Desain penelitian ini yaitu deskriptif survei, dengan mengambil sampel dari populasi sebagai subjek penelitian. Berdasarkan data dari subjek penelitian dideskripsikan berkaitan dengan penggunaan media berbasis TIK dalam Pembelajaran di SD sebagai objek penelitian, dengan sampel guru kelas III$\mathrm{V}$ di SD Muhammadiyah 9 Malang sebagai subjek penelitian.

\section{Teknik Pengumpulan Data}

Pengumpulan data pada penelitian ini dilakukan dengan teknik observasi, wawancara dan dokumentasi.

1. Observasi

Observasi dilakukan untuk mengumpulkan data tentang praktik pembelajaran yang dilakukan guru, dan kompetensi guru dalam menerapkan media berbasis komputer dalam pembelajaran tematik terpadu

2. Wawancara

Wawancara dilakukan kepada guru yang mempraktikkan pembelajaran tematik dengan menggunakan media berbasis komputer. Kegiatan wawancara juga untuk mengetahui kendala yang dihadapi serta upaya guru dalam mengatasi kendala tersebut

3. Dokumentasi

Dokumentasi dilakukan untuk mengumpulkan data tentang berbagai peristiwa dalam proses pembelajaran melalui foto, dokumen berupa media berbasis komputer yang digunakan guru.

\section{Kuesioner}

Kuesioner atau angket dilakukan untuk mengumpulkan data tentang kompetensi dan respon guru dalam pembelajaran menggunakan media berbasis komputer.

\section{Instrumen Penelitian}

Penelitian ini menggunakan instrumen penelitian untuk mebantu keterlaksanaan pengumpulan data. Instrumen untuk mengumpulkan data, penelitian ini menggunakan instrumen yang berupa: Lembar/pedoman observasi kepada guru, pedoman wawancara, dan lembar kuesioner. Pedoman observasi berisi berisi tentang deskripsi kompetensi guru di sekolah dasar dalam mengimplementasi pembelajaran menggunakan media berbasis komputer. Pedoman wawancara berisi tentang 
pertanyaan terkait kendala dan upaya guru dalam mengatasi kendala saat implementasi media. Lembar kuesioner berisi pernyataan tentang kompetensi dan respon guru dalam pembelajaran menggunakan media berbasis komputer

\section{Teknik Analisa Data}

Analisis data dilakukan secara deskriptif baik secara kualitatif maupun kuantitatif. Sebagaimana pada umumnya analisis data secara kualitatif dilakukan dengan tahap-tahap sebagai berikut: pemaparan data, reduksi data, kategorisasi data, penafsiran/pemaknaan, dan penyimpulan hasil analisis data.

Data yang diperoleh melalui observasi, wawancara, dokumentasi, dan kuesioner kemudian ditulis ulang dan dipaparkan apa adanya sesuai dengan lapangan, kemudian data dipilih dan disesuaikan dengan fokus penelitian, setelah melalui proses analisis dalam kerangka memperoleh data yang sahih dengan member check, triangulasi data, dan pelacakan mendalam, kemudian disimpulkan dan dimaknai.

\section{HASIL DAN PEMBAHASAN}

1.1 Kompetensi guru dalam menerapkan media pembelajaran berbasis komputer pada pembelajaran tematik terpadu

a. Guru kelas III

Guru kelas III telah menerapkan pembelajaran dengan menggunakan media berbantuan komputer. Sebelum pembelajaran dimulai, kegiatan seharihari sebagai wujud pembiasaan yang dilakukan guru bersama siswa yaitu berdoa bersama, mengaji surat pendek, dan pembacaan asmaul husna. Setelah pembiasaan selesai guru melakukan presensi siswa.

Selain kegiatan tersebut guru bersama siswa melakukan pembiasaan sebagai wujud gerakan literasi. Siswa dengan bimbingan guru diberi kesempatan untuk membaca semua bahan bacaan yang disediakan di sudut kelas. Setelah membaca salah satu siswa mengungkapkan dan membagikan informasi yang sudah didapat kepada teman-temannya ke depan kelas.

Terkait media yang digunakan di kelas III, guru sering menggunakan media berbasis komputer jenis multimedia presentasi, video pembelajaran, dan memanfaatkan jaringan internet untuk mencari/sebagai sumber materi. Guru memiliki keterampilan dalam mengemas materi dalam media ppt presentasi. Guru tidak merasa kesulitan dalam membuat media ppt presentasi. Guru lebih suka membuat media ppt presentasi karena mudah menggunakannya, dan praktis digunakan dalam pembelajaran.

Media berbasis komputer yang digunakan guru seringkali digunakan karena di kelas terdapat sarana multimedia berbasis teknologi berupa TV LED atau LCD Proyektor dan Personal komputer lengkap dengan instalasi hardware audio. Guru dengan mudah memanfaatkan fasilitas tersebut terutama dalam menerapkan pembelajaran menggunakan media berbasis komputer.

Lebih lanjut kompetensi guru terkait pembuatan media berbasis komputer jenis video, belum begitu tampak. Hal ini dikarenakan video pembelajaran yang dibutuhkan lebih praktis mengunduh langsung dari internet dengan memanfaatkan fasilitas youtube. Jika video terlalu panjang atau materi di dalam video terlalu panjang, guru mengurangi durasi video dengan menggunakan aplikasi. Dapat dikatakan bahwa kemampuan guru secara keseluruhan sudah baik dan mampu mengoperasikan dan membuat media berbasis komputer.

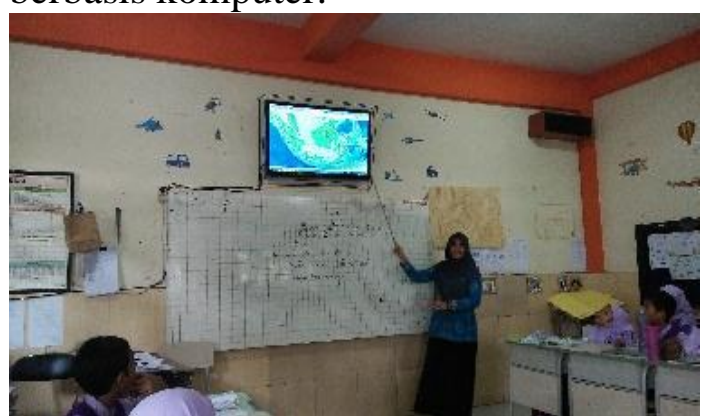

Gambar 1. Guru di kelas III menggunakan media video animasi untuk menjelaskan tentang gejala alam

Dari gambar tersebut tampak bahwa guru sedang menggunakan media animasi dalam pembeljaaran. Inovasi yang beragam pula yang dikembangkan dalam bidang media pembelajaran. Hal ini dipilih agar siswa tidak merasa bosan selama mengikuti pembelajaran.

\section{b. Guru kelas IV}


Kompetensi guru kela IV dalam menerapkan media berbasis komputer sudah bagus. Hal ini ditandai dengan kemampuan guru mengoperasikan media berbasis komputer. Guru mampu memproduksi media powerpoint presentasi. Lebih lanjut guru kelas IV juga menggunakan aplikasi tambahan misalnya timer yang dapat digunakan sebagai sarana tambahan dalam melakukan evaluasi. Misalnya dalam mengerjakan soal matematika. Siswa dalam mengerjakan diberikan keterbatasan waktu, jika aplikasi timer menunjukkan waktu sudah berakhir, maka siswa secara sportif harus berhenti mengerjakan soal kemudian dikumpulkan atau bahkan dibahas secara bersamasama.

Lebih lanjut kompetensi guru terkait pembuatan media berbasis komputer jenis video, masih sebatas memanfaatkan video yang sudah dipersiapkan sebelumnya yaitu dengan mengunduh video dari jaringan internet youtube. Hal ini dikarenakan video pembelajaran yang dibutuhkan lebih praktis mengunduh langsung dari internet dengan memanfaatkan fasilitas youtube. Jika video terlalu panjang atau materi di dalam video terlalu panjang, guru mengurangi durasi video dengan menggunakan aplikasi atau software untuk mengedit video. Hal ini dilakukan untuk mengantisipasi proporsi materi yang terlalu dalam atau bahkan tidak sesuai untuk di sampaikan dalam pembelajaran. Guru secara aktif memfiltrat materi agar sesuai dengan karakterisik usia dan kebutuhan siswa. Dapat dikatakan bahwa kemampuan guru secara keseluruhan sudah baik, inovatif, dadn mampu mengoperasikan serta membuat media berbasis komputer.

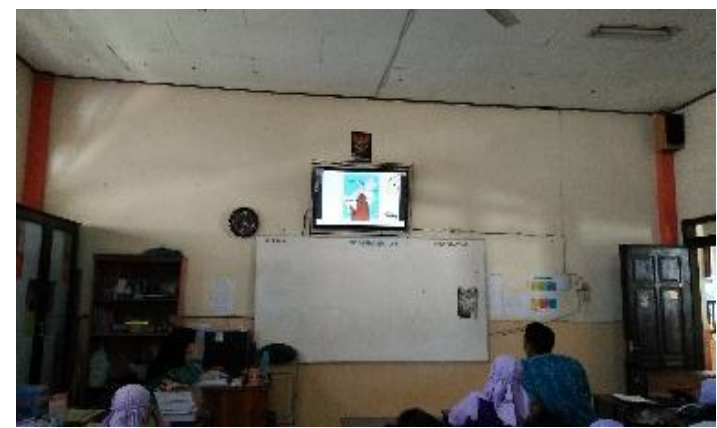

Gambar 2. Media jenis video animasi yang digunakan di kelas IV dan program timer untuk evaluasi
Akan tetapi kendala dalam penggunakan media ini adalah posisi layar yang sedikitterlalu tinggi dan dekan dengan siswa. Maka upaya yang dilakukan guru adalah dengan menggeser bangku ke belakang sehingga siswa siswi tidak terlalu dekat dengan layar.

\section{c. Guru kelas V}

Guru kelas V banyak menggunakan media berbasis komputer jenis presentasi power point. Namun yang menjadi pembeda dari power point guru-guru yang lain yaitu terletak pada multimedia interaktif. media ppt yang sudah dihasilkan oleh guru kelas V dimanfaatkan selain sebagai alat untuk menyampikan materi juga digunakan sebagai alat evaluasi. Tampak pada hasil observasi yang dilakukan oleh peneliti yaitu pemanfaatan media ppt interaktif yang didesain seperti kuis who wants to be a millionaire. Media digunakan secara klasikal maupun kelompok. Lebih lanjut respon siswa tampak bahwa siswa tertarik saat belajar menggunakan media ppt interaktif. Siswa juga semangat dan antusias dalam menjawab pertanyaan atau kuis yang ada dalam media.

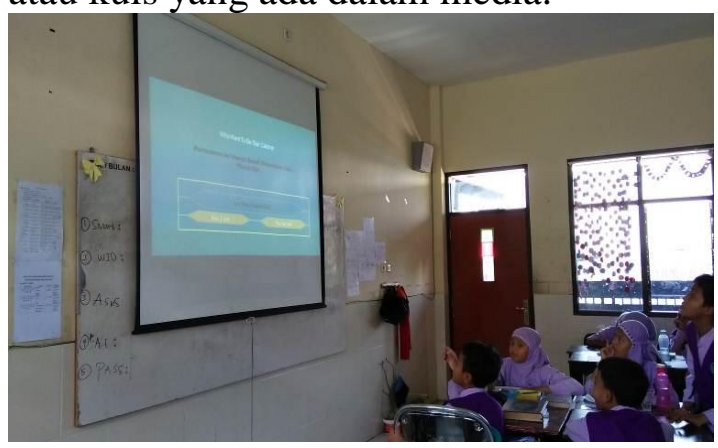

Gambar 3. Media prsentasi untuk alat evaluasi di kelas V

Berdasarkan hasil yang sudah diapaparkan dapat ditemukan temuan lain bahwa penerapan media berbasis kompurter yang digunakan guru memiliki kontribusi tidak hanya dalam kemudahan penyampaiaan materi, tetapi juga pada siswa yang menjadi termotivasi dan tertarik untuk belajar. Hal ini sesuai dengan hasil penelitian (Leow, 2014:109) yaitu Pembelajaran dengan berbasis komputer (MMSLE) multimediamediated student-centred learning environment dapat meningkatkan prestasi belajar, mahasiswa lebih aktif dan termotivasi dalam proses pembelajaran. Berdasarkan hal tersebut sebagai guru layaknya selalu membuat terobosan dan inovasi baru menerapkan media berbasis 
komputer agar pembelajaran semakin menarik dan hasil belajar siswa juga mengalami peningkatan.

1.2 Kendala yang dihadapi guru dalam menerapkan media berbasis komputer pada pembelajaran tematik terpadu

Berdasarkan dari keseluruhan hasil wawancara, angket, dan observasi. Dapat dikatakan bahwa tidaka ada kesulitan yang berarti terkait penerapan media berbasis komputer bagi guru-guru di SD Muhammadiyah 9 Malang. Kesulitan dan hambatan yang dapat dirasakan bagi guru-guru dari penerapan media berbasis komputer hanya terkait eror aplikasi yang digunakan, serta gejala teknis dari kelistrikan. Misalnya terjadinya listrik mati yang menyebabkan proses pembelajaran menjadi terhambat. Jika hal ini terjadi, maka guru secara kondisional mengganti media pembelajaran dengan yang lain misalnya menggunakan bendabenda yang ada di sekitar sekolah.

1.3 Upaya guru untuk mengatasi kendala dalam menerapkan media berbasis komputer pada pembelajaran tematik terpadu.

Berdasarkan hasil wawancara dan angket yang sudah disebarkan oleh peneliti, dapat dikatakan bahwa kendalakendala yang terjadi di lapangan dapat segera diatasi baik oleh guru-guru maupun pihak sekolah. Adapun upaya yang dilakukan oleh guru-guru yaitu dengan meningkatkan pelatihan, mengembangkan produk media berbasis komputer dengan mempelajari aplikasi pembuatan media berbasis komputer. Selain itu pihak sekolah terutama Kepala sekolah juga memberikan andil dalam mengatasi kendala penerapan media berbasis komputer yaitu dengan mengirimkan guru-guru untuk mengikuti pelatihan pembuatan bahan ajar dan media pembelajaran, pelatihan dalam bidang komputer dan jaringan/internet.

\section{SIMPULAN}

Berdasarkan hasil yang sudah dipaparkan maka kesimpulan sebagai berikut:

a. Guru memiliki kompetensi yang bagus dan inovatif dalam menerapkan media berbasis komputer dengan ditinjukkan oleh keterampilan dan inovasi media yang sudah digunakan guru dalam pembelajaran tematik. Guru cenderung memanfaatkan sarana dan prasarana yang ada di kelas dengan mengintegrasikan media melalui jaringan internet yang sudah disediakan oleh sekolah sehingga guru lebih mudah mengakses materi maupun jenis media berbasis komputer lainnya.

b. Hambatan guru dalam menerapkan pembelajaran berbasis komputer terletak pada teknis kelistrikan misalnya listrik mati atau aplikasi yang eror. Hal ini tidak menjadikan persoalan yang berarti karena guru masih bisa mengantisipasi dengan baik. Adapun strategi yang digunakan salah satunya dengan mengunduh terlebih dahulu materi atau video sebelum pembelajaran atau penyampaian materi.

c. Upaya yang dilakukan guru maupun puhak sekolah dalam meningkatkan keterampilan dan kompetensi guru dalam menerapkan pembelajaran berbasis komputer dengan mengikuti pelatihan terkait media dan pengembangan bahan ajar berbasis teknologi. Selain itu guru-guru juga mempelajari beberapa program baru terkait pembuatan media berbasis komputer secara mandiri. Misalnya mengembangkan media powerpoint berbasis interaktif yang dapat diintegrasikan sebagai bahan ajar maupun alat evaluasi bagi siswa.

\section{SARAN}

Adapun saran yang dapat diberikan yaitu:

a. Guru dapat menginovasi jenis media pembelajaran lain yang berbasis komputer dengan menggunakan multimedia, atau sejenisnya.

b. Materi yang disajikan dalam media bisa ditambahkan dengan konten tidak hanya dari buku, tetapi bisa memanfaatkan sumber-sumber lain yang dirasa lebih komplek dan kekinian/up todate. 
c. Guru dapat memanfaatkan dan memproduksi sendiri media presentasi atau video pembelajaran dengan memanfaatkan aplikasi sederhana untuk memperkaya jenis media berbasis komputer yang lain.

\section{DAFTAR PUSTAKA}

Arkün, S. \& Akkoyunlu, B. 2008. A Study on the Development Process of a Multimedia Learning Environment According to the ADDIE Model and Students' Opinions of the Multimedia Learning Environment. Interactive Educational Multimedia University of Barcelona, (17). (Online), (http://www.raco.cat/index.php/ie $\mathrm{m} /$ article/viewFile/205357/27389 5), diakses 8Maret 2017

Arsyad, Azhar. 2014. Media Pembelajaran. Jakarta: Raja Grafindo Persada

Fogarty R, 1991. The Mindfull School: How to Integrate the Curricula. Palatine, Illinois: Skylight Publishing, inc.

Heinich, R., et.al. 2005. Instructional Media and Technology for Learning. (8th ed). Englewood Cliffts New Jersey: Prentice-Hall

Jamil, Suprihatiningrum. 2013. Strategi Pembelajaran Teori \& Aplikasi. Jogjakarta: Ar-Ruzz Media

Leow, Fui-Theng. 2014. Interactive Multimedia Learning: Innovating Classroom Education in A Malaysian University. TOJET: The Turkish Online Journal of Educational Technology, 13 (2). (Online), (http://files.eric.ed.gov/fulltext/EJ 1022913.pdf), diakses 20Juni 2017

Majid, A. 2014. Pembelajaran Tematik Terpadu. Bandung: PT Remaja Rosda Karya.
Mishra, S. \& Ramesh, C. Sharma. 2005. Interactive Multimedia in Education and Training. United States of America: Idea Group Publishing (an imprint of Idea Group Inc.)

Peraturan Menteri Pendidikan dan Kebudayaan Nomor 57 Tahun 2014Tentang Kerangka Dasar dan Struktur Kurikulum Sekolah Dasar/Madrasah Ibtidaiyah

Peraturan pemerintah No 32 Tahun 2013 Tentang Perubahan Atas Peraturan Pemerintah Nomor 19 Tahun 2005 Tentang Standar Nasional Pendidikan.

Prastowo, A. 2013. Pengembangan Bahan Ajar Tematik Panduan Lengkap Aplikatif. Yogyakarta: Diva Press

Pribadi, Benny. A. 2011. Model Assure untuk Mendesain Pembelajaran Sukses. Jakarta: Dian RakyatPuskur Balitbang Depdiknas. 2006. Model Pembelajaran Tematik.

Trianto. 2007. Model Pembelajaran Terpadu dalam Teori dan Praktek. Jakarta:Prestasi Pustaka. 